\title{
膝前十字勒帯損傷に伴う前内方回旋 不安定性についての検討
}

\author{
前田病院整形外科

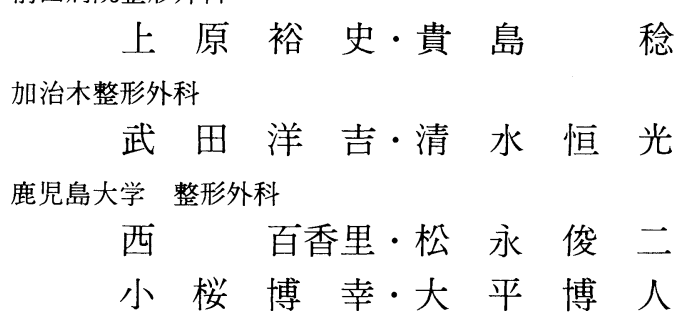

Anteromedial Rotatory Instability in the Anterior Cruciate Ligament Rupture

by

Hirofumi Uehara and Minoru Kijima,

Department of Orthopaedic Surgery, Maeda Hospital.

Yokichi Takeda and Tsunemitu Shimizu, Kajiki Orthopaedic Hospital.

Yukari Nishi, Shunji Matsunaga, Hiroyuki Kozakura and Hiroto Ohira.

Department of Orthopaedic Surgery, Kagoshima University.

45 cases of anterior cruciate ligament rupture were evaluated on anteromedial rotatory instability (AMRI) and the effect of anterior cruciate ligament reconstruction, 8 were acute and others were old injuries. The incidence of AMRI was 69\% (31 cases). 32 cases had medial meniscus tears and AMRI was severe in the cases of peripheral tears. The grade three ruptures of the medial collateral ligament was seen in two cases and in them AMRI was severe. All cases underwent reconstruction of anterior cruciate ligament with Leeds-Keio artificial ligament by the arthroscopic method. Medial meniscus tears were treated with the meniscal suture in 14 cases, subtotal meniscectomy in 8 cases and the partial meniscectomy in 10 cases. Medial collateral ligament ruptures were reconstructed in the cases of more than grade three. The results of each operative method were successful, and AMRI was noted in 4 cases postoperatively. But in these cases there were no disability related to AMRI.

は じめに

ACL 損傷に合併する anteromedial rotatory instability一以下 AMRI一に対し後内側関節包の縫縮を 行うか否かについては異論のあるところである3).

我々は, AMRI を伴う ACL 損傷例に対しては, III
度以上の MCL 損傷の合併がなければ ACL 形成術と, 合併する半月板損傷に対する手術のみを行っている゙2). 今回, Leeds-Keio 人工勒帯を用い鏡視下 ACL 形 成術を施行した損傷例について, 内側半月板損傷と $M$ $\mathrm{CL}$ 損傷の $\mathrm{AMRI} へ$ の関与と, 本術式による術後の $\mathrm{A}$ MRI の改善度について検討したので報告する. 


\section{対 象 症 例}

症例は，スポーツ，肉体労働復帰を希望する ACL 損傷例で，男28例，女17例の計45例である．年齢は 16 ～46才，平均 26 才，術後経過期間は $5 \sim 37$ 月，平均 15 力月である，45例中， 8 例は新鮮例，37例は陳旧例 である。

内側支持機構の損傷は，32例に内側半月板損傷を認 め, その内訳は, 辺縁部損傷が16例, 縦断裂等その他 の断裂が16例であった。

$\mathrm{MCL}$ 損傷は II 度が 3 例， II 度以上のものが 2 例で あった。

我々の行っている AMRI の徒手検査法は, 森 (1) の報 告した medial pivot shift test あり, 被検者は仰臥位で股関節外転, 外旋位, 膝90度 屈曲位とする，検者は，2-4指を膝蓋骨前面に，拇指 を脛骨内顆後面にあて，拇指を前外方に押すと，脛骨 内顆の前外側方向への回旋動摇を触知する (図 1)。A MRI の程度を左右差のあるものを+ 1 , 著明な不安定 性を示すが脱臼しないものを+2, 脱臼するものを+ 3 と分類した。

\section{結果}

AMRIの出現頻度は，新鮮例 8 例中 4 例 (50\%)，陳 旧例37例中27例（73\%）で，全症例中では，31例69\% である.

臨床的に MCL 損傷のない 40 例について内側半月板 損傷の AMRIへの関与を検討した。新鮮例 7 例中, 内 側半月板辺縁部損傷を伴う 2 例は, いずれも AMRI は +3 で，内側半月板損傷のない 5 例は 1 例のみ+ 1 で 他は（一）であった。陳旧例33例では，内側半月板の 辺縁部損傷が13例で，うち10例に+3，2例に+2， 計 $92 \%$ AMRI がみられ，(一) は1例のみであった。 その他の損傷型は 14 例で，4例に+3，4例に+1， 計 $57 \%$ AMRIをみ，（一）も6例43\%にみられた。 内側半月板損傷のないものは 6 例で, 1 例に+ 3 , 各 々 1 例に+2, + 1 , 計 $50 \%$ に AMRIをみ, (-) は 3 例であった (図 2).

内側支持機構の障害の程度が大きい内側半月板辺縁 部損傷では+3の AMRI の出現率が高くなっていた.

MCL 損傷と AMRI の関係について検討した．Ｉ度 の MCL 損傷 3 例中，半月板損傷を伴う 1 例に，+ 3

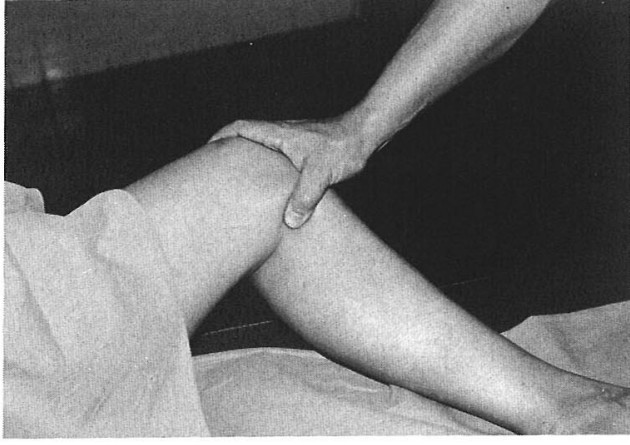

図1 AMRI の徒手検査手技 +1 : 軽度の左右差あり +2 : 著明な左右差あり. 脱臼せず. $+3:$ 脱臼

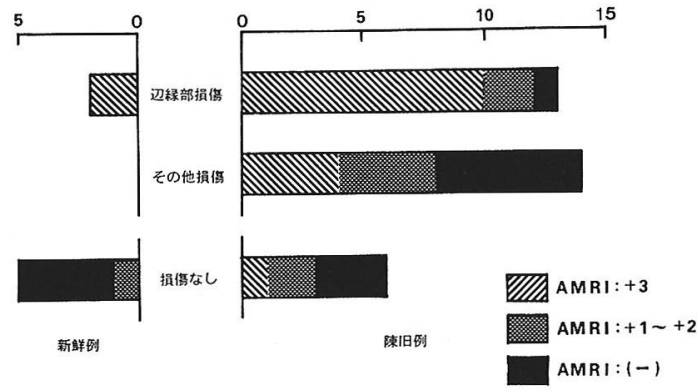

図 2 内側半月板損傷の AMRI への関与

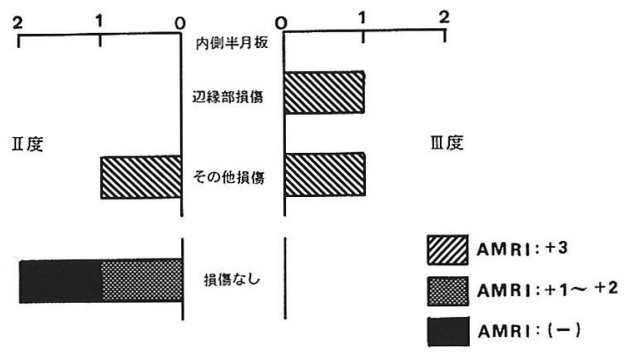

图 3 内側々副勒帯損傷の AMRI への関与

の AMRI を認め，損傷のない 2 例中 1 例は+ 1 ，他の 1 例は $(-)$ であった。四度の損傷 2 例は，いずれも 半月板損傷を伴い, AMRI はいずれも +3 と高度であ った (図 3 )。

手術は，全例に Leeds-Keio 人工勒帯を用いた鏡視 下 ACL 形成術を，内側半月板損傷32例中，14例に縫 合術を，8例に亜全摘術を，10例に部分切除術を施行 


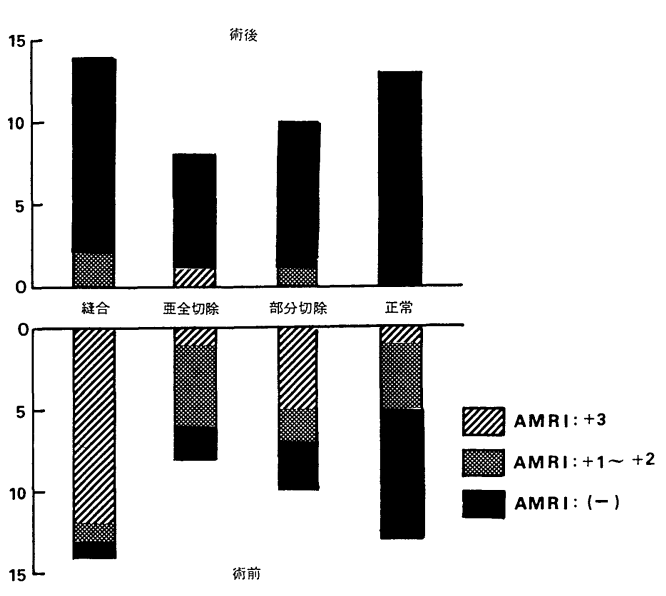

図 4 内側半月板手術々式による, 術後の AMRI の改善度

した. MCL 損傷に対しては，且度以上の 2 例に MC L形成術を施行した。

いずれの術式においても AMRI はよく改善しており， ACL 形成術を行えば内側半月板の術式に関係なく良 好な結果が得られている. 術後 AMRIの残存は 4 例で, 1 例は+ 3 , 他の 3 例は+ 1 であり, 縫合術に 2 例, 覀全摘術, 部分切除術に各々 1 例がみられた. その要 因としては, + 3 と+1の 2 例は ACL 形成術そのも のの不成功例で, AMRI が残存している. +1 の 2 例 は, MCL III度および II度の損傷例で外反動摇性が残 存している(困 4 ).

術後の自覚的, スポーツ, 肉体労働への復帰度を検 討した，スポーツ復帰を目的とした症例は30例，肉体 労働への復帰を目的とした症例は15例である。膝を意 識することなく，スポーツ，肉体労働に復帰した症例 は, スポーツで14例47\%, 肉体労働で14例 $93 \%$, 膝の 不安感のため, 活動レベルの低下をみたものが, スポ 一ツで 9 例であった. 症状の改善が不十分で, スポー ツ, 肉体労働を中止したものが各々 1 例あり, 他疾患 や社会的理由でスポーツを中止したものが 6 例みられ た.
AMRI の残存例 4 例でみると, 1 例は完全に元のス ポーツに復帰し，2 例は他疾患や社会的理由で中止し ている. 1 例は肉体労働を中止しているが，これは膝 の疼痛が残っているためであり, AMRIの残存は術後 の活動性への影響はなかった。

以上の結果は ACL 損傷に AMRI が合併しても, A CL 形成術を確実におこなえば，AMRIに対し特に外 科的治療を必要としない事を示している.

\section{結語}

1. AMRIにはACL 損傷の関与が大きく, MCL 損傷, 内側半月板損傷でより高度となる.

2. AMRI は, ACL 形成と半月板の治療で改善し, II 度までの MCL 損傷は外科的治療を必要としない.

\section{文献}

1）貴島 稔 - 他：関節鏡視下前十字勒帯形成術. 関節 鏡, $11: 65-69,1986$.

2）貴島 稔・他：鏡視下前十字勒帯形成術の術式と術 後成績. 中部整災誌, 32 巻 1 号投稿中.

3）城守国斗・他：陳旧性前十字勒帯損傷に伴った内側 支持機構損傷例の検討. 中部整災誌, $29: 2029-2031$, 1986.

4）森 繁・他：膝関節の前内側, 前外側回旋不安定性 を示した 1 例. 膝, $11: 26-31,1985$.

質 問福岡整形外科 小林晶 AMRI が出現する時に, MM の処置は大切だが, subtotal meniscechmy の成績が良いのは何故か?

\section{解 答前田病院 上原 裕史}

AMRI の出現要因としては, ACLの関与が大きく, その他に内側支持機構, 内側半月板等も考えられるが, ACLの正確な形成による十分な機能再建が行なわれ ると, その他の要因の関与が小さいとき AMRI の消失 をみる。 